\title{
Effect of Topical Application of Binahong [Anredera cordifolia (Ten.) Steenis] Leaf Paste in Wound Healing Process in Mice
}

\author{
Gurwinder Kaur a/p Gurcharan Singh ${ }^{1}$, Novi Vicahyani Utami ${ }^{2}$, Hermin Aminah Usman ${ }^{3}$
}

${ }^{1}$ Faculty of Medicine, Universitas Padjadjaran, ${ }^{2}$ Department of Pharmacology and Therapy, Faculty of Medicine, Universitas Padjadjaran, ${ }^{3}$ Department of Pathology Anatomic, Faculty of Medicine,

Universitas Padjadjaran/Dr. Hasan Sadikin General Hospital, Bandung, Indonesia

\begin{abstract}
Background: Wound caused by trauma poses challenging daily clinical problems for physicians in hospitals and other health services. It has high risk for mortality and morbidity. Binahong [Anredera Cordifolia (Ten.) Steenis] plant originates from China and can be found abundantly in Indonesia. The objective of this research is to investigate the effect of topical application of Binahong leaf paste on wound healing process.

Methods: A laboratory experimental study was conducted at the Pharmacology Laboratory, Universitas Padjadjaran, from October to December 2012 by using 27 Mus Muscularis mice which were divided into 3 groups: group 1 (sodium chloride 0.9\%), group 2 (Binahong) and group 3 (povidone iodine $5 \%$ ). Binahong leaves were crushed and were mixed with water to make a paste. The application was given for 12 days. On day zero, $1.0 \mathrm{~cm}^{2}$ of wound was incised at the back of the mice, and further on day 1, 4, 8 and 12, the percentage of wound contraction was measured. The data was analyzed using Mann-Whitney test.

Results: The study indicated that the percentage of wound contraction in group 2 on day 4 (1.17\%), day $8(23.7 \%)$ and day $12(76.14 \%)$ is the highest among all groups. The result showed that the comparison between binahong and $\mathrm{NaCl}$ was highly significant on day $12, \mathrm{p}=0.001(\mathrm{p}<0.05)$ and the data for comparison between Binahong and povidone iodine on day 12 was significant with $p=0.003(p<0.05)$.

Conclusions: Topical application of Binahong leaf paste shows better result in wound healing process of Mus muscularis mice. From this study it can be concluded that binahong promotes wound healing and can be used for home remedies for wound care and as an alternative traditional way to treat wound. [AMJ.2014;1(1):6-11]
\end{abstract}

Keywords: Binahong [Anredera Cordifolia (Ten.) Steenis], povidone iodine, wound healing

\section{Efek Aplikasi pasta daun Binahong [AnrederaCordifolia (Ten.) Steenis] secara topikal dalam proses penyembuhan luka pada tikus jenis Musmuscularis}

\begin{abstract}
Abstrak
Latar Belakang: Luka yang disebabkan oleh trauma menjadi masalah klinis yang menantang bagi para dokter di rumah sakit maupun bagi petugas kesehatan lainnya dalam melakukan pekerjaan sehari-hari. Luka yang timbul tersebut memiliki risiko yang tinggi terhadap mortalitas dan morbiditas. Tanaman Binahong [AnrederaCordifolia (Ten.) Steenis] berasal dari Cina dan banyak ditemukan di Indonesia. Tujuan dari penelitian untuk mengetahui efek dari aplikasi pasta daun Binahong secara topikal terhadap proses penyembuhan luka.

Metode: Penelitian eksperimental ini dilakukan di Laboratorium Farmakologi, Universitas Padjadjaran, mulai Oktober-Desember 2012, menggunakan tikus jenis MusMuscularis sebanyak 27 ekor, dibagi menjadi 3 kelompok: kelompok 1 (natrium klorida 0,9\%), kelompok 2 (pasta daun Binahong) dan kelompok 3 (povidone iodine 5\%). Daun Binahong dihancurkan dan ditambahkan sedikit air sehingga menjadi bentuk pasta. Perlakuan diberikan selama 12 hari. Pada hari 0 dilakukan insisi pada punggung tikus untuk membuat luka sebesar 1,0 cm2. Persentase kontraksi luka akan dinilai pada hari ke-1, 4, 8, dan 12. Kontraksi luka
\end{abstract}

Correspondence: Gurwinder Kaur a/p Gurcharan Singh, Faculty of Medicine, Universitas Padjadjaran, Jalan Raya Bandung-Sumedang Km.21, Jatinangor, Sumedang, Indonesia, Phone: +628170206321, Email: gurwin2789@yahoo.com 
adalah pengurangan luas pada area luka. Hasil penilaian tersebut akan dibandingkan pada tiap kelompok untuk melihat efektivitas aplikasi topikal pasta daun Binahong. Data akan dianalisis dengan uji MannWhitney.

Hasil: Hasil penelitian menunjukkan bahwa persentase kontraksi luka kelompok 2 pada hari ke-4 (1,17\%), hari ke-8 (23,7\%), dan hari ke-12 (76,14\%) adalah lebih tinggi dibandingkan dengan kelompok lainnya. Hasil juga menunjukkan bahwa terdapat perbedaan sangat signifikan antara perbandingan Binahong dan natrium klorida pada hari ke-12, dengan $p=0,001(p<0,05)$. Perbandingan antara Binahong dan povidone iodine pada hari ke-12 juga menunjukkan hasil signifikan dengan $p=0,003(p<0,05)$.

Simpulan: Aplikasi pasta daun Binahong secara topikal menunjukkan hasil yang lebih baik dalam proses penyembuhan luka pada tikus jenis Musmuscularis. Dari penelitian ini dapat disimpulkan bahwa Binahong mempercepat penyembuhan luka serta dapat digunakan untuk perawatan luka di rumah dan sebagai cara alternatif yang bersifat tradisional untuk mengobati luka.

Kata kunci: Binahong [AnrederaCordifolia (Ten.) Steenis], penyembuhan luka, povidone iodine

\section{Introduction}

Wound caused by trauma poses challenging clinical problems for physicians in hospitals and other health services in their daily work. ${ }^{1}$ It is a pathological process which results in the disruption of the continuity of the skin and its underlying tissues due to physical injury. ${ }^{2,3}$

It is estimated that 10.5 of 1000 population currently suffers from acute wound. ${ }^{4}$ Acute wound takes 5-10 days to heal. ${ }^{1}$ Acute wound that is not managed well can progress into chronic wounds which are more difficult to manage. ${ }^{4}$ Chronic wounds take longer time to heal, which may range from weeks up to 2 years. ${ }^{1}$ Worldwide, 6 million people suffers from chronic wounds. ${ }^{4}$

Wound is a major problem that relates to the high risk of mortality and morbidity. ${ }^{1}$ Wound management is important for the healing process to decrease mortality and morbidity. Healing process is essential to restore the continuity and function of the skin and its underlying tissues to their normal condition. ${ }^{5,10}$

Therefore, to be able to treat wound as soon as possible at home, some communities tend to prefer herbal medicine compared to conventional medicine because it is more accessible. In addition, herbal medicine is less expensive, less toxic, less side effects and easier to use. ${ }^{4,6}$ One of the herbal remedies used by the Indonesian community to treat wound is Binahong [Anredera cordifolia (Ten.) Steenis]. ${ }^{7}$ This basellaceae family plant is originated from China. ${ }^{8}$ It is found abundantly in Indonesia and contains active components that are beneficial. It has many pharmacological properties such as antimicrobial, anti-inflammatory, anticancer, antioxidant, antifungal, and antitumor properties. ${ }^{8-10}$ The active components in this plant include saponin, tannins, terpenoids, alkaloids and flavonoid.

Saponin seems to have an effect on the activation and synthesis of transforming growth factor- $\beta$ (TGF- $\beta 1$ ) and also on modification of TGF- $\beta 1$ and TGF- $\beta 2$ receptors in fibroblasts. ${ }^{7}$ This is essential for the formation of the collagen matrix in the remodeling phase. ${ }^{5}$ Therefore, binahong is expected to increase the rate of the healing process.

Binahong leaf extract increases wound healing process ${ }^{10}$ However there is no research that has been conducted to observe the effect of topical application of Binahong leaf paste on wound healing process. This study can provide information to the community about the benefits of Binahong leaf paste for wound healing.

In this research, topical application of Binahong and povidone iodine in Mus muscularis mice was compared. Povidone iodine is an antiseptic agent that serves as standard requirement for every wound care and for pre-operative procedures in hospitals and general practices worldwide. ${ }^{11}$

The percentage of wound contraction as the effect of topical application of Binahong leaf paste on wound healing process in Mus muscularis mice was compared to that of the povidone iodine. The higher percentage of wound contraction indicates better wound healing process.

\section{Methods}

This research is an experimental study on Mus Muscularis mice which were randomly divided into 3 groups. Each group contained 27 Mus muscularis model mice that were male, aged 
2-3 months, weighing 17-25 g, and healthy.

Fresh Binahong leaves used in this study was obtained from Jalan Sukawening, Bandung. The leaves were identified in the Plant Taxonomy Laboratory of Universitas Padjadjaran. Next, the fresh leaves were washed thoroughly few times under running tap water. Sterilization was done by steaming the leaves in boiling water with a temperature of 100 Celsius in a cooker for 15-20 minutes. The leaves were then dried in room temperature for few minutes and then crushed thoroughly using a stir bar. Some water was added to create the paste form.

An incision was performed toinduce wounds in mice. Injection of $1.0 \mathrm{ml}$ phenobarbitol was performed at the dorsal midline to keep the mice unconscious and to eliminate pain sensation during wound incision. After 15-20 minutes, all the mice were checked for their consciousness and the experiment was started after the mice were unconscious. Next, all mice were shaved at the back around the area of dorsal midline region using a shaver. Then, 1.0 $\mathrm{cm}^{2}$ diameter was measured using the vernier caliper and a permanent marker was used to create a square on the mice to indicate the site of incision. After few seconds, a scalpel was used to make the incision over the marked area. Skin on the back of the mice was pinched between the thumb and index finger to make sure the skin that will be wounded is incised and cut using scissors.

The groups were treated by $\mathrm{NaCl} 0.9 \%$, binahong leaf paste and $5 \%$ povidone iodine respectively. Before the binahong leaf paste was applied, the wounded area was cleaned. This procedure was performed twice daily for
12 days.

The percentage of wound healing from the group treated with binahong was then compared to the mice treated with $\mathrm{NaCl}$ and povidone iodine. To measure wound healing process in this study, the percentage of wound contraction (\%) technique has been implemented. The size of the wounded area was measured using ruler in centimeter $(\mathrm{cm})$ and was calculated. Progressive changes in the wounded area were examined on day 1, 4, 8, and 12 . The percentage of wound contraction is calculated as a percentage of the reduction in wounded area using the following formula: [(initial wound area-specific day wound area) / initial wound area] $\times 100 \%$.

The data was analyzed statistically using Non Parametric (Mann-Whitney) test. The $\mathrm{p}$-value for statistic significancy was set on $(<0.05)$.

The research was conducted during the period of October-November 2012 at the Pharmacology and Therapy Laboratory, Faculty of Medicine, Universitas Padjadjaran, Bandung, Indonesia. The study was carried out with prior approval from the Animal Ethical Committee, Faculty of Medicine, Universitas Padjadjaran.

\section{Results}

A total of 27 mice were recruited in this study. During observation, it was found that mice number 5 (group 2) and mice number 1 (group 3) had large increase in wound area, therefore excluded from the study.

From Figure 1, it can be seen that there was no changes in mean for all the 3 groups

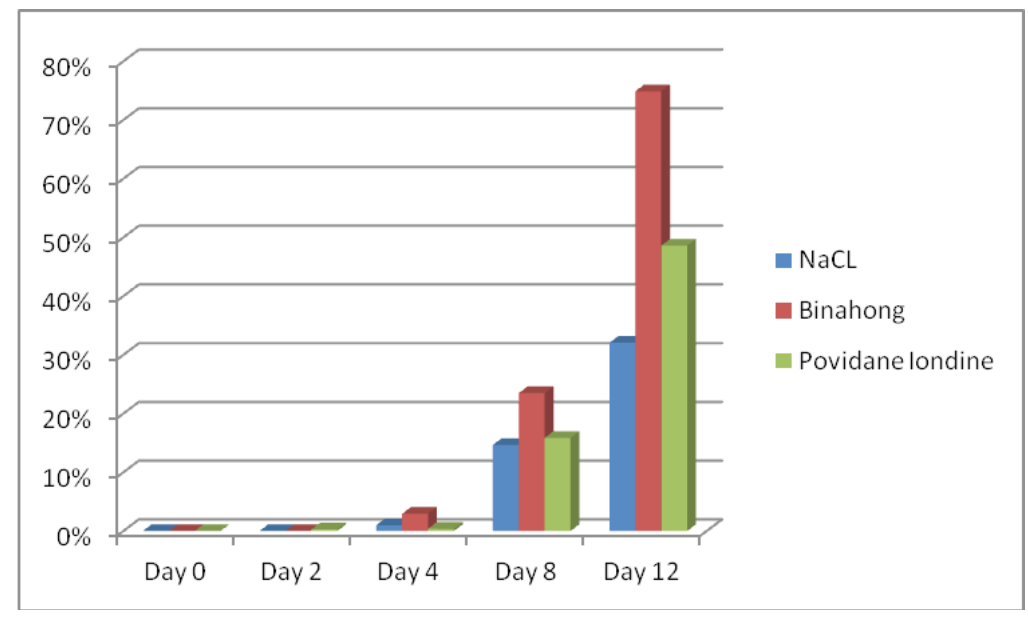

Figure 1 Mean Percentage of Wound Contraction in Three Groups on day 0, 1, 4, 8 and 12 
during the $1^{\text {st }}$ day. The control group which only received topical application of $\mathrm{NaCl}$ twice daily, showed decrease in percentage $(-1.15 \%)$ on day 4 . On day 8 , the percentage increased to $15.03 \%$. It was shown that the mean of the highest percentage of the control group from day 1 to day 12 was $32 \%$. Meanwhile, for the treatment group which received topical application of binahong twice daily, it can be seen that there was an increase in percentage of wound area from day 1 to day 12 with the highest percentage of $76.14 \%$. On day 4 , the mean percentage was $1.17 \%$ and on day 8 the mean was $23.7 \%$. It can be also seen from table 1 that for group 3 , which received topical application of povidone iodine twice daily, the highest mean percentage from day 1 to day 12 was $48.67 \%$. On day 4 , the mean percentage was $-0.56 \%$, and on day 8 it was $15.77 \%$.

There was no significant difference between the percentage of wound contraction (\%) in group $1 \& 2$ on day 1,4 and 8 as the $\mathrm{p}$-value was more than 0.05 . The $\mathrm{p}$-value on day 12 was less than 0.05 which showed that it was significant, thus it can be concluded that Binahong is better than sodium chloride in wound healing process.

There was no significant difference between the wound contraction (\%) percentage in group 2 and 3 on day 1, 4 and 8 as the p-value was more than 0.05 . The $p$-value on day 12 was less than 0.05 which showed that it was significant. Thus, it can be concluded that Binahong is better than povidone iodine in wound healing process.

\section{Discussion}

Wound healing of the skin can be divided into 3 phases: inflammatory, proliferative and remodeling phase. The inflammatory phase is the initial phase which ranges from 2-6 days. $^{6}$ Binahong leaf paste has antiseptic and anti-inflammatory effects. One of the active ingredients of binahong plant is saponin. It has properties that make the wound site microbefree. This compound binds to the bacteria and alters its membrane permeability, thus resulting in destruction of the bacteria. ${ }^{12}$

Therefore, saponin prevents delayed wound healing caused by microorganisms. In addition, saponin increases TGF- $\beta 1$ activity which recruits the inflammatory cells to the wounded site, thus accelerating the inflammatory phase. ${ }^{5}$ Interestingly, in group treated with povidone iodine, there was a decrease in wound percentage. Povidone iodine only contains antiseptic property. It has free iodine elements which interact with the enzymes and proteins of the cell wall leading to disruption of the structure. This results in death of the microbes. ${ }^{11}$ The decrease in wound percentage could be caused by certain fungus or bacterial spore infection to the mice. Povidone iodine may require a longer time to kill certain microorganisms.

The next phase of wound healing process is the proliferative phase (day 6-10). ${ }^{5}$ The proliferative phase (reepithelization and neovascularisation) which is optimum on day $5 .{ }^{6}$ The wound healing as expected was better in phase 2 (day 4-8) in all groups, and the healing process was the best in group 2 as it is shown to have a higher wound contraction percentage. This might be due to saponin property in Binahong leaves that acts as an angiogenic agent. It regulates the vascular endothelial growth factor (VEGF) expression which causes an increase in the mitogenic activity of the endothelial cells for the formation of new blood vessels. Saponin, thus, increases the angiogenesis process in the proliferative phase. ${ }^{5}$ In contrast, in this phase it can be seen that there is no difference in increment in wound contraction percentage in both $\mathrm{NaCl}$ and povidone iodine. Therefore, both treatments have no effect on wound healing process.

The last phase in the wound healing process is the remodeling phase (day $10-12$ ).

Table 1 Mann-Whitney Test Results on The Comparison of Percentage of Wound Contraction between Group 1 (Sodium Chloride/ control) and Group 2 (Binahong)

\begin{tabular}{ccccc}
\hline \multirow{2}{*}{ Day } & \multicolumn{2}{c}{ Wound contraction percentage } & p-value & Interpretation \\
\cline { 2 - 3 } & Group 1 & Group 2 & & Not significant \\
\hline 1 & 0 & 0 & 0.743 & Not significant \\
4 & -1.15 & 1.17 & 0.888 & Not significant \\
8 & 15.03 & 23.17 & 0.200 & Significant \\
\hline
\end{tabular}


Table 2 Mann-Whitney Test Results on the Comparison of Wound Contraction Percentage between Group 2 (Binahong) and Group 3 (Povidone Iodine)

\begin{tabular}{ccccc}
\hline \multirow{2}{*}{ Day } & \multicolumn{2}{c}{ Wound contraction percentage } & p-value & Interpretation \\
\cline { 2 - 3 } & Group 2 & Group 3 & & Not significant \\
\hline 1 & 0 & 0 & 0.442 & Not significant \\
4 & 1.17 & -0.56 & 0.878 & Not significant \\
8 & 23.17 & 15.77 & 0.328 & Significant \\
12 & 76.14 & 48.67 & 0.003 & \\
\hline
\end{tabular}

The data shows that in term of the percentage of wound contraction on day 12, the highest percentage was observed in the group treated with Binahong compared to the groups treated with povidone iodine and $\mathrm{NaCl}(76 \%, 48 \%$ and $32 \%$ respectively). From this data, Binahong is better than povidone iodine and $\mathrm{NaCl}$. This can be supported based on the theory that saponin has an effect on the activation and synthesis of TGF- $\beta 1$ and also in modification of TGF- $\beta 1$ and TGF- $\beta 2$ receptors on fibroblasts. Therefore, a direct effect in the process of wound healing is due to the increase of TGF- $\beta 1$ and TGF- $\beta 2$ receptor expressions on fibroblasts. This will stimulate the fibronectin synthesis. Fibronectin is a protein that mediates cellular adhesive interactions, by cross-linking with collagen. ${ }^{5}$ This process is to form provisional extracellular matrix which is an important step in the remodeling phase. ${ }^{5}$

The data was not significant from day 0 to day 8 and significant on day 12 in all groups. The comparison between group 1 and 2 in table 2, shows a marked difference $\mathrm{p}=0.001$. This shows that binahong is clearly better than sodium chloride. Lastly, for the comparison between group 2 (binahong) and group 3 (povidone iodine) in table 3 , the statistical results seem to be highly significant on day $12(0.003)$. The less p-value indicates the better effect of the treatment used in the experiment. Therefore, the most prominent effect of binahong can be observed on day 12 (remodeling phase), the day when the active compounds gave the most effect. In addition to its effect on TGF- $\beta 1$, saponin also increases the hydroxyproline content of the granulation tissue which strengthens and supports the collagen matrix in the remodeling phase. ${ }^{5}$

Compared to other researches, which is a study on ethanolic extract of Anredera cordifolia (Ten.) or Steenis leaves which shows that the extract of binahong improves wound healing in guinea pigs. Based on the results of the research, saponin, flavanoids and alkaloids found in the leaves help in the healing process. ${ }^{10}$ Another wound healing based research shows that saponin has antibacterial effect which helps in accelerating healing process. ${ }^{12}$

In conclusion, topical application of Binahong [Anredera cordifolia (Ten.) Steenis] leaf paste shows a beneficial effect on higher wound contraction percentage in wound healing process in Mus muscularis mice suggesting that topical application of Binahong leaf paste has more benefits compared to povidone iodine. Further research has to be conducted focusing on the histopathological results on the effect of Binahong leaf paste in wound healing process. This will provide more evidents as the cells involved in wound healing can be observed and evaluated. Therefore, Binahong leaf paste can be use widely as an alternative for wound care after further research is conducted.

\section{References}

1. Velnar T, Bailey T, Smrkolj V. The wound healing process: an overview of the cellular and molecular mechanisms. J Int Med Res. 2009;37(5):1528-42.

2. Solanki R. Treatment of skin diseases through medicinal plants in different region of the world. IJBR. 2011;2(1):73-80.

3. Arunachalam KD, Subashini S. Preliminary phytochemical investigation and wound healing activity of Myristica Andamanica leaves in Swiss albino mice. J Med Plant Res. 2011;5(7):1095-106.

4. Sasidharan S, Nilawatyi R, Xavier R, Latha LY, Amala R. Wound healing potential of Elaeis guineensis Jacq leaves in an infected albino rat model. Molecules. 2010;15(5):3186-99.

5. William S, Rebecca G. Robbins and Cotran Pathologic Basis of Disease. $8^{\text {th }}$ ed.; 
Philadelphia: Saunders Elsevier; 2010.

6. Singer AJ, Clark RA. Cutaneous wound healing. $\mathrm{N}$ Engl J Med. 1999;341(10):738-46.

7. Yuliani SH, Fudholi A, Pramono S, Marchaban. The effect of formula to physical properties of wound healing gel of ethanolic extract of Binahong [Anredera cordifolia (Ten.) Steenis]. IJPSR. 2012;3 (11):4254-9.

8. Sumartiningsih S. The effect of Binahong to hematoma. World Academy of Science, Engineering and Technology. 2011;5(6): 679-81.

9. Astuti SM, Sakinah M, Andayani R, Risch A. Determination of saponin compound from Anredera cordifolia (Ten.) Steenis plant
(Binahong) to potential treatment for several diseases. Journal of Agricultural Science. 2011;3(4):224-32.

10. Miladiyah I, Prabowo BR. Ethanolic extract of Anredera cordifolia (Ten.) Steenis leaves improved wound healing in guinea pigs. Univ Med. 2012;31(1):4-11.

11. KumarS, Babu R, Reddy I,Uttam A. Povidone Iodine-Revisited. IJDA. 2011;3(3):617-20.

12. Keerthi AAP, Mendis WSJ, Jansz ER, Ekanayake S, Perera MSA. A preliminary study on the effects of an antibacterial steroidal saponin from Borassus flabellifer L. fruit, on wound healing. J Natn Sci Foundation Sri Lanka. 2007;35(4):263-5. 